\title{
The evolving evidence base for coronary artery bypass grafting and arterial grafting in 2021: How to improve vein graft patency
}

Dominique Vervoort, MD, MPH, MBA, ${ }^{\mathrm{a}, \mathrm{b}}$ Abdullah Malik, HBSc, ${ }^{\mathrm{a}, \mathrm{c}}$ and Stephen E. Fremes, MD, MSc, FRCSC, FACP, FACC ${ }^{\mathrm{a}, \mathrm{b}, \mathrm{c}, \mathrm{d}}$

Coronary artery bypass grafting $(\mathrm{CABG})$ is foundational to managing multivessel coronary artery disease. The internal thoracic artery (ITA) remains the gold standard for left anterior descending artery (LAD) grafting. Although saphenous vein grafts (SVGs) may be considered for non-LAD targets, the right ITA (RITA) and radial artery (RA) are associated with improved outcomes ${ }^{1}$ and thus are more commonly used for CABG. A recent systematic review and a network meta-analysis of 150,000 patients ${ }^{2,3}$ highlighted that the use of RA was associated with a lower risk of major adverse cardiovascular events (MACE) at 5 and 10 years and with a higher rate of patency at 5 years. Moreover, the growing interest in and evidence supporting multiple arterial grafting has resulted in their overall favorable consideration in professional society guidelines for myocardial revascularization, ${ }^{4}$ even though most of the published evidence supporting the RITA is observational. Conversely, up to $20 \%$ of SVGs reportedly fail within 1 year post-CABG, owing primarily to technical errors, thrombosis, and intimal hyperplasia, and an additional $20 \%$ to $25 \%$ fail by 10 years post-CABG owing to arteriosclerosis. ${ }^{5}$ The Project of ExVivo Vein Graft Engineering via Transfection (PREVENT) IV, the largest angiographic trial to date $(n=3014$ across 107 sites), found angiographic SVG occlusion in $>26 \%$ of grafts overall and at least $1 \mathrm{SVG}$ occlusion in $42 \%$ of patients at 12 to 18 months post-CABG. ${ }^{6}$ A recent metaanalysis of early SVG occlusion suggests that approximately $11 \%$ of grafts occlude within 1 year post-CABG. ${ }^{7}$

Despite the evidence supporting use of the RITA and RA, the potential of SVGs cannot be dismissed, given that

From the a Division of Cardiac Surgery, ${ }^{\mathrm{b}}$ Institute of Health Policy, Management and Evaluation, ${ }^{\mathrm{c}}$ Temerty Faculty of Medicine, and ${ }^{\mathrm{d}}$ Division of Cardiac Surgery, Department of Surgery, Schulich Heart Centre, Sunnybrook Health Sciences Centre, University of Toronto, Toronto, Ontario, Canada.

Received for publication July 30, 2021; accepted for publication Sept 20, 2021; available ahead of print Sept 24, 2021.

Address for reprints: Stephen E. Fremes, MD, MSc, FRCSC, FACP, FACC, Division of Cardiac Surgery, Department of Surgery, Schulich Heart Centre, Sunnybrook Health Sciences Centre, University of Toronto, 2075 Bayview Ave, Room H4 05, Toronto, ON, Canada M4N 3M5 (E-mail: stephen.fremes@sunnybrook.ca). JTCVS Techniques 2021;10:102-9

2666-2507

Copyright (C 2021 The Author(s). Published by Elsevier Inc. on behalf of The American Association for Thoracic Surgery. This is an open access article under the CC BY-NC-ND license (http://creativecommons.org/licenses/by-nc-nd/4.0/).

https://doi.org/10.1016/j.xjtc.2021.09.038

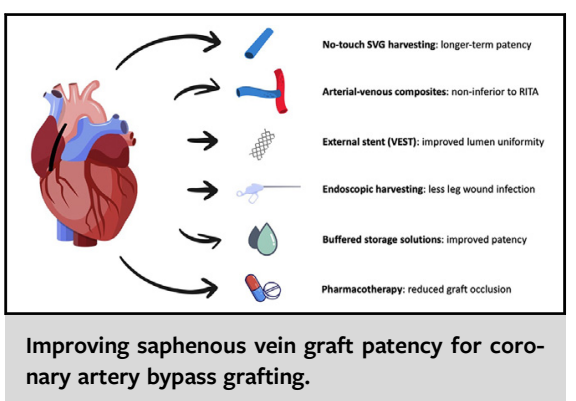

CENTRAL MESSAGE

Saphenous vein grafts remain the most common conduits for coronary artery bypass grafting despite limited durability. Various techniques have arisen to improve vein graft patency and outcomes.

See Commentaries on pages 110 and 112 .

$>80 \%$ of CABG conduits in the United States currently comprise SVGs. ${ }^{4}$ In addition, there are specific contraindications to using the RITA or RA. Accordingly, methods to improve vein graft patency are warranted. In this Invited Expert Opinion, we describe the no-touch saphenous vein graft (NT-SVG), ITA anastomosed SVG composites, externally supported SVGs (VEST), endoscopically harvested SVGs, SVG storage solutions, and pharmacotherapy as promising techniques to improve vein graft patency (Figure 1).

\section{NT-SVG HARVESTING}

NT-SVG is a variation of SVG whereby harvesting of the vein graft occurs with a small amount of surrounding tissue. The pedicled graft is harvested atraumatically and without manual dilatation and is checked for leaks when subjected to aortic pressure. Souza ${ }^{8}$ was the first to report a case series on NT-SVG in 1996. Since then, an increasing number of reports have shown improved patency compared with conventional SVG (C-SVG) as well as patency approaching that achieved with the left ITA (LITA) over the long term. 


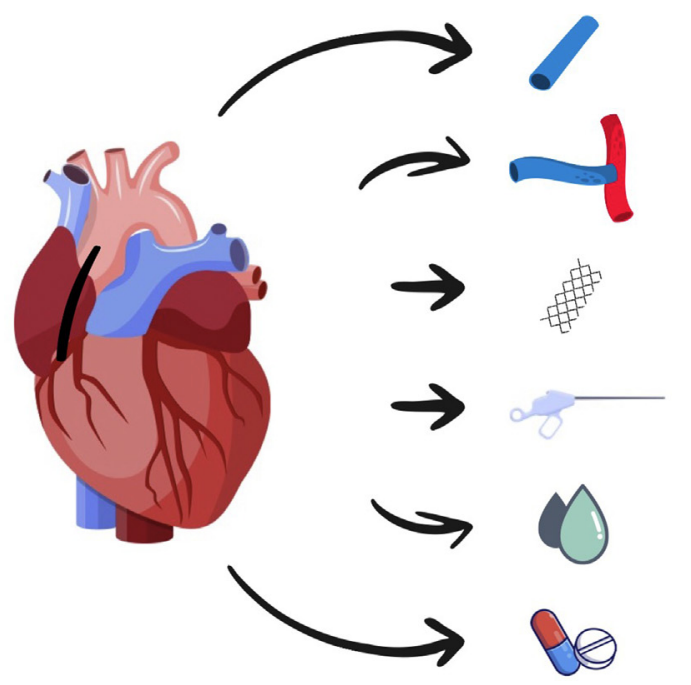

No-touch SVG harvesting: longer-term patency

Arterial-venous composites: non-inferior to RITA

External stent (VEST): improved lumen uniformity

Endoscopic harvesting: less leg wound infection

Buffered storage solutions: improved patency

Pharmacotherapy: reduced graft occlusion

FIGURE 1. Comparison of techniques to improve saphenous vein graft (SVG) patency for coronary artery bypass grafting. RITA, Right internal thoracic artery; VEST, externally supported SVG.

Recent reports even suggest that NT-SVG is associated with improved health-related quality of life after CABG. ${ }^{9}$ However, large studies showing improved clinical outcomes are lacking, and the effects on health-related quality of life need to be confirmed in a standardized manner in future studies.

The growing evidence supporting NT-SVG has led to favorable considerations in recent societal guidelines. The 2018 European Society of Cardiology/European Association for Cardio-Thoracic Surgery Guidelines on Myocardial Revascularization recommend NT-SVG as a class IIa, level of evidence (LoE) B recommendation when an open harvesting technique is used. ${ }^{10}$ These recommendations were based on the work of Samano and colleagues, ${ }^{11}$ who showed 16-year patency with NT-SVG, and Dreifaldt and colleagues, ${ }^{12}$ who found a similar 8 -year patency for NT-SVG compared with RA grafts. The 2011 American College of Cardiology Foundation/American Heart Association (AHA) Guideline for CABG Surgery did not specify any SVG technique in its recommendations. ${ }^{13}$

To date, 4 randomized controlled trials (RCTs) have compared the performance of NT-SVG harvesting compared with C-SVG harvesting, 3 of which reported patency results (Table 1). At a mean follow-up of 18 months, Souza and colleagues ${ }^{15}$ reported a higher rate of leg wound complications with NT-SVG compared with C-SVG $(11.1 \%$ vs $4.3 \% ; \mathrm{n}=156) .{ }^{15}$ The group later reported patency rates in the 2 groups of patients of $90 \%$ versus $76 \%(P=.01)$ at a mean follow-up of 8.5 years $^{16}$ and $83 \%$ versus $64 \%(P=.03)$ at a mean follow-up of 16 years ${ }^{11}$ with NT-SVG patency rates not statistically worse than those of LITA grafts. ${ }^{11,16}$ SUPERIOR SVG ${ }^{18}$ $(\mathrm{n}=250)$ was the first multicenter angiographic trial comparing NT-SVG and C-SVG. The trial's primary outcome, SVG occlusion or cardiovascular mortality at
1 year, was not statistically different between the groups (5.5\% for NT-SVG vs $10.6 \%$ for C-SVG; $P=.15$ ), and neither was SVG stenosis or total occlusion $(7.8 \%$ for NT-SVG vs $15.0 \%$ for C-SVG; $P=.11$ ). However, the NT-SVG group had a significantly greater incidence of early vein harvest site infection at 1 month $(23.3 \%$ vs $9.5 \%$ for C-SVG; $P<.01$ ). Leg assessment scores (Total Leg Scores) were significantly worse in the NT-SVG group at 1 month (adjusted difference, 2.58; $P<.001$ ) and 3 months (adjusted difference, 2.30; $P=.002$ ) but were comparable in the 2 groups at 1 year (adjusted difference, $1.12 ; P=.407)$. Finally, Pettersen and colleagues randomized 100 patients in the IMPROVE-CABG trial to pedicled versus conventional harvesting to assess 5-year angiographic SVG function. ${ }^{19}$ Early perioperative findings have been promising, suggesting comparable postoperative bleeding and leg wound infection rates, and long-term findings are expected in the near future.

Meta-analytic findings, ${ }^{18}$ including SUPERIOR SVG, concluded that graft occlusion was significantly reduced with NT-SVG versus C-SVG as treated (odds ratio [OR], $0.49 ; 95 \%$ confidence interval $[\mathrm{CI}], 0.29-0.82 ; P=.007)$ at 1 year across 3 trials and 1 observational study. A recent network meta-analysis of patency confirmed significantly reduced graft occlusion in NT-SVG compared with C-SVG. ${ }^{27}$ Although a majority of the early NT-SVG experience and reports stem from the same center, 2 major ongoing RCTs will add further to our knowledge of NT-SVG. In Sweden and Denmark, SWEDEGRAFT ${ }^{20}$ has recruited 902 patients to assess graft failure by computed tomography angiography, repeat target vessel revascularization, or death at 2 years as the primary composite endpoints and leg wound assessment scores as secondary endpoints (ClinicalTrials.gov identifier 


\begin{tabular}{|c|c|c|c|c|c|c|}
\hline Study & $\begin{array}{l}\text { Year of primary } \\
\text { trial completion }\end{array}$ & $\begin{array}{l}\text { Sample } \\
\text { size }\end{array}$ & Follow-up & Intervention(s) & Primary outcomes & Secondary outcomes \\
\hline \multicolumn{7}{|l|}{ No-touch SVG } \\
\hline $\begin{array}{l}\text { Dreifaldt et al } \\
\text { Dreifaldt et } \mathrm{al}^{12}\end{array}$ & 2014 & 108 & $\begin{array}{l}36 \text { mo (mean) } \\
97 \text { mo (mean) }\end{array}$ & $\begin{array}{l}\text { No-touch SVG vs radial artery } \\
\text { graft }\end{array}$ & $\begin{array}{l}\text { SVG patency by angiography at } \\
\text { follow-up }\end{array}$ & $\begin{array}{l}\text { Incidence of perioperative and } \\
\text { postoperative myocardial } \\
\text { infarction, death, or need for } \\
\text { revascularization }\end{array}$ \\
\hline Souza et al ${ }^{15}$ & 2011 & 156 & 18 mo (mean) & No-touch SVG vs standard open & SVG patency by angiography at & Stenosis in grafts at follow-up \\
\hline Souza et $\mathrm{al}^{16}$ & & & 8.5 y (mean) & vs intermediate technique & follow-up & \\
\hline Samano et $\mathrm{al}^{11}$ & & & 16 y (mean) & & & \\
\hline PATENT-SVG ${ }^{17}$ & 2012 & 17 & $12 \mathrm{mo}$ & $\begin{array}{l}\text { No-touch SVG vs standard open } \\
\text { harvesting }\end{array}$ & $\begin{array}{l}\text { SVG morphometry and early } \\
\text { markers of vascular smooth } \\
\text { muscle cell activation }\end{array}$ & $\begin{array}{l}\text { Leg wound healing and functional } \\
\text { recovery at } 3 \text { and } 12 \mathrm{mo}\end{array}$ \\
\hline SUPERIOR-SVG ${ }^{18}$ & 2015 & 250 & $12 \mathrm{mo}$ & $\begin{array}{l}\text { No-touch SVG vs standard open } \\
\text { harvesting }\end{array}$ & $\begin{array}{l}\text { Incidence of complete SVG } \\
\text { occlusion at } 1 \text { y or death due to } \\
\text { cardiovascular or unknown } \\
\text { causes }\end{array}$ & $\begin{array}{l}\text { - Significant stenosis and } \\
\text { MACCE at } 1 \mathrm{y} \\
\text { - Leg adverse events and leg } \\
\text { quality of life at } 1 \mathrm{y}\end{array}$ \\
\hline IMPROVE-CABG $^{19}$ & 2016 & 100 & $5 y$ & $\begin{array}{l}\text { Pedical vs conventional SVG } \\
\text { harvesting }\end{array}$ & $\begin{array}{l}\text { SVG function by angiography at } \\
6 \mathrm{mo} \text { and } 5 \mathrm{y}\end{array}$ & $\begin{array}{l}\text { - Morphological appearance of } \\
\text { SVG at } 6 \text { mo and } 5 \text { y } \\
\text { - Leg wound complications at } \\
6 \text { wk } \\
\text { - Postoperative complications at } \\
\text { discharge, } 6 \text { wk, } 6 \text { mo, and } 5 \text { y }\end{array}$ \\
\hline SWEDEGRAFT $^{20}$ & Ongoing & 902 & $2 \mathrm{y}$ & $\begin{array}{l}\text { No-touch SVG vs standard open } \\
\text { harvesting }\end{array}$ & $\begin{array}{l}\text { - SVG occlusion or stenosis on } \\
\text { CCTA at } 2 \text { y or earlier } \\
\text { - Death within } 2 \text { y }\end{array}$ & $\begin{array}{l}\text { - Wound healing in SVG sites at } \\
2 \mathrm{y} \\
\text { - Incidence of MACE at } 2 \mathrm{y}\end{array}$ \\
\hline Wang et $\mathrm{al}^{21}$ & Ongoing & 2655 & $12 \mathrm{mo}$ & $\begin{array}{l}\text { No-touch SVG vs standard open } \\
\text { harvesting }\end{array}$ & SVG occlusion on CCTA at 3 mo & $\begin{array}{l}\text { - MACCE at } 3 \text { and } 12 \text { mo } \\
\text { - SVG occlusion at } 1 \mathrm{y}\end{array}$ \\
\hline \multicolumn{7}{|c|}{ ITA anastomosed SVG composite } \\
\hline SAVE-RITA ${ }^{22}$ & 2012 & 224 & $5 y$ & $\begin{array}{l}\text { SVG vs RITA as Y-composite } \\
\text { graft }\end{array}$ & $\begin{array}{l}\text { SVG or RITA patency by } \\
\text { angiography at } 1 \mathrm{y}\end{array}$ & $\begin{array}{l}\text { - Overall survival at } 1 \text { and } 4 \text { y } \\
\text { - Incidence of MACCE at } 1 \text { and } \\
4 \text { y }\end{array}$ \\
\hline \multicolumn{7}{|c|}{ Externally supported SVGs (VEST) } \\
\hline VEST I ${ }^{23}$ & 2013 & 30 & $12 \mathrm{mo}$ & VEST-supported vein graft & $\begin{array}{l}\text { - SVG intimal hyperplasia area } \\
\text { by intravascular ultrasound at } \\
1 \mathrm{y} \\
\text { - Incidence of MACCE at } 6 \mathrm{wk}\end{array}$ & $\begin{array}{l}\text { SVG failure, ectasia, and } \\
\text { Fitzgibbon classification at } 1 \mathrm{y}\end{array}$ \\
\hline
\end{tabular}




\begin{tabular}{|c|c|c|c|c|c|c|}
\hline Study & $\begin{array}{l}\text { Year of primary } \\
\text { trial completion }\end{array}$ & $\begin{array}{l}\text { Sample } \\
\text { size }\end{array}$ & Follow-up & Intervention(s) & Primary outcomes & Secondary outcomes \\
\hline VEST III $^{24}$ & 2019 & 184 & $2 y$ & VEST-supported vein graft & $\begin{array}{l}\text { - Proportion of SVGs with } \\
\text { perfect patency at } 2 \text { y }\end{array}$ & $\begin{array}{l}\text { - Intimal hyperplasia area at } 2 \text { y } \\
\text { - MACCE at } 2 \text { y } \\
\text { - SVG failure at } 2 \text { y } \\
\text { - Early SVG failure at } 6 \text { mo }\end{array}$ \\
\hline VEST IV ${ }^{25}$ & 2013 & 30 & $4.5 \mathrm{y}$ (mean) & VEST-supported vein graft & $\begin{array}{l}\text { - MACCE at follow-up } \\
\text { - Intimal hyperplasia and } \\
\text { thickness at follow-up } \\
\text { - Graft occlusion and Fitzgibbon } \\
\text { perfect patency rates at follow- } \\
\text { up }\end{array}$ & Not specified \\
\hline VEST Pivotal & Ongoing & 224 & $5 \mathrm{y}$ & VEST-supported vein graft & $\begin{array}{l}\text { Intimal hyperplasia area and graft } \\
\text { occlusion at } 1 \mathrm{y}\end{array}$ & $\begin{array}{l}\text { - Lumen diameter uniformity at } \\
1 \mathrm{y} \\
\text { - Vein graft failure ( } \geq 50 \% \\
\text { stenosis) by cardiac } \\
\text { angiography at } 1 \mathrm{y} \\
\text { - Incidence of MACCE annually } \\
\text { over } 5 \mathrm{y}\end{array}$ \\
\hline \multicolumn{7}{|c|}{ SVG storage solutions } \\
\hline Perrault et al ${ }^{26}$ & 2016 & 125 & $12 \mathrm{mo}$ & DuraGraft graft storage solution & $\begin{array}{l}\text { - Change in wall thickness } \\
\text { between } 1 \text { and } 3 \text { mo } \\
\text { - Change in maximum } \\
\text { narrowing between } 1 \text { and } \\
12 \text { mo }\end{array}$ & $\begin{array}{l}\text { MDCT angiography } \\
\text { measurements for wall } \\
\text { thickness, lumen diameter, } \\
\text { maximum narrowing, and } \\
\text { vessel diameter at } 3 \text { and } 12 \text { mo } \\
\text { - Changes in MDCT } \\
\text { angiography measurements } \\
\text { between } 1 \text { and } 3 \text { mo and } \\
\text { between } 1 \text { and } 12 \text { mo } \\
\text { - Incidence of SVG thrombosis } \\
\text { and occlusion, MACE, angina, } \\
\text { arrhythmias, shortness of } \\
\text { breath, significant stenosis }\end{array}$ \\
\hline
\end{tabular}


NCT03501303). In China, Wang and colleagues ${ }^{21}$ have recruited 2655 patients in a multicenter RCT with graft occlusion at 3 months as the primary endpoint and a major adverse cardiovascular and cerebrovascular event (MACCE) at 3 and 12 months postoperatively and graft occlusion at 12 months postoperatively as secondary endpoints (ClinicalTrials.gov identifier NCT03126409).

\section{ITA ANASTOMOSED SVG COMPOSITE}

An arterial-arterial composite graft is a strategy to achieve more complete arterial revascularization with fewer conduits while also reducing aortic manipulation and decreasing neurologic events. An arterial-venous composite graft is usually considered a bail-out strategy for patients with limited conduit options and/or a hostile aorta. Theoretical advantages of arterial-venous composite are that the SVG is subjected to dampened pressure waves from the ITA compared with the aorta, whereas the SVG may be bathed with vasodilatory, antithrombotic, and antiatherosclerotic mediators from the ITA due to a proximal anastomosis to the LITA. However, a graft size mismatch and the greater sensitivity of arterial grafts to competitive flow compared with SVGs may lead to the steal sign or string sign (ie, diffuse narrowing of part of or the entire graft). This has been observed in up to 7\% of RA grafts. ${ }^{4}$ In addition, the usual concerns about T-graft (ie, side-to-end) anastomoses remain, including obstruction due to kinking of the graft or misplacement of the pedicle, competition of flow with bypassed vessels, and the need for technical experience.

Current trial evidence evaluating ITA-anastomosed SVG composites remains scarce (Table 1). The SAVE RITA trial $(n=224)$ found that SVG composites were noninferior to the RITA as Y-composites proximally anastomosed to LITAs graft at 1 year $(97.1 \%$ for SVG composites vs $97.1 \%$ for RITA composite grafts; $P<.001$ ), albeit with a large $(8 \%)$ noninferiority margin. ${ }^{22}$ In addition, a recent propensity-matched analysis of 196 patients suggested further improvement of 1-year arterial-venous composite patency when using the NT-SVG for the venous limb (97.3\% for NT-SVG vs $92.6 \%$ for minimal manipulation; $P=.051) .^{28}$ To date, these superb results have been reported only from a single center, however; larger multiinstitutional studies are needed to confirm these findings before the widespread adoption of this technique.

\section{VEST}

A more recently introduced technique is the use of a cobalt-chromium mesh stent to externally support the SVG and improve graft hemodynamic properties. The VEST device (Vascular Graft Solutions, Tel Aviv, Israel) has been approved for clinical use in Europe following a series of VEST trials (Table 1$)$. VEST I $(\mathrm{n}=30)$ was a first-in-human trial highlighting a reduced mean intimal hyperplasia area $\left(4.37 \pm 1.40 \mathrm{~mm}^{2}\right.$ vs $5.12 \pm 1.35 \mathrm{~mm}^{2}$;
$P=.04)$ at 1 year for stented SVGs versus nonstented SVGs. ${ }^{23}$ VEST III $(\mathrm{n}=184)$ later confirmed these findings at 2 years with a substantially larger sample. ${ }^{24}$ Although patency rates were comparable for stented and nonstented SVGs $(78.3 \%$ vs $82.2 \% ; P=.43)$, the Fitzgibbon patency scale was improved significantly (OR, 2.02; $P=.03)$, and mean intimal hyperplasia area $\left(3.07 \pm 0.37 \mathrm{~mm}^{2}\right.$ vs $\left.3.96 \pm 0.38 \mathrm{~mm}^{2} ; \quad P<.001\right)$ and thickness $(0.26 \pm 0.03 \mathrm{~mm}$ vs $0.34 \pm 0.31 \mathrm{~mm} ; P<.001)$ were reduced. The longer but smaller VEST IV $(n=21)$ found higher Fitzgibbon perfect patency with VEST at 1 year $(81 \%$ vs $48 \% ; P=.002)$ and 5 years $(79 \%$ vs $50 \%$; $P=.002)$ compared with C-SVG. ${ }^{25}$ Vest II $(\mathrm{n}=30)$ provided a postmarket clinical assessment of the VEST device to the right coronary artery to identify graft failure by CT angiography at 3 to 6 months. ${ }^{29}$ Avoidance of external stent fixation to anastomoses and the use of metallic clips to ligate SVG branches was found to improve the patency of stented SVGs to the right coronary territory $(86.2 \%)$, in agreement with VEST I findings $(88.8 \%){ }^{23}$

These findings are encouraging and are being longitudinally assessed in the VEST EU Registry ( $\mathrm{n}>1000)$, an ongoing prospective cohort (2017-2025). Although VEST is yet to be approved in North America, the Food and Drug Administration is running the VEST Pivotal RCT $(\mathrm{n}=224)$ (ClinicalTrials.gov identifier NCT03209609) to confirm earlier trial results. The primary study outcome is intimal hyperplasia as assessed by intravascular ultrasound at 12 months.

\section{ENDOSCOPICALLY HARVESTED SVG}

To address the leg wound infections, healing issues, and associated postoperative pain observed with NT-SVG, endoscopic harvesting of the SVG has been proposed and successfully adopted. However, the technical complexity of endoscopic SVG harvesting requires a longer learning curve and thus is more commonly performed by experienced surgeons, which compromises residents' ability to adequately learn this technique. ${ }^{30}$ A meta-analysis of 267,525 patients found that leg wound infections and complications were significantly reduced and graft occlusion was increased across all studies, although the latter finding was not confirmed by analysis of 2 RCTs alone. ${ }^{31}$ This is recognized by the 2018 European Society of Cardiology/ European Association for Cardio-Thoracic Surgery guidelines, ${ }^{10}$ which recommend that endoscopic harvesting of SVGs be performed by experienced surgeons to reduce harvest site infection (class IIa, LoE A recommendation). Despite its advantages, a potential risk is $\mathrm{CO}_{2}$ embolism development during endoscopic SVG harvesting, reported in up to $4 \%$ of procedures in an early report, ${ }^{32}$ which can be mitigated by lower $\mathrm{CO}_{2}$ insufflation pressures as well as surgeon experience and continuous transesophageal echocardiographic monitoring. ${ }^{33}$ 
The large PREVENT IV trial $(\mathrm{n}=3000)$ found that at 12 to 18 months, endoscopic harvesting was associated with higher SVG failure rates compared with open harvesting $(46.7 \%$ vs $38.0 \% ; P<.001) .{ }^{34}$ At 3 years, all-cause mortality, myocardial infarction, and repeat revascularization were more frequent $(20.2 \%$ vs $17.4 \%$; adjusted hazard ratio, $1.22 ; 95 \%$ CI, $1.01-1.47 ; P=.04)$. In the EPIC trial $(\mathrm{n}=183)$, endoscopic harvesting was associated with lower SVG patency at 9 months compared with open harvesting $(79.2 \%$ vs $90.8 \%)$, which may be a result of variable endoscopic harvesting experience. ${ }^{35}$ The recent Randomized Endo-Vein Graft Prospective (REGROUP) trial $(\mathrm{n}=1150)$ found that the primary composite endpoint of all-cause mortality, nonfatal myocardial infarction, and repeat revascularization was similar following endoscopic and open harvesting at 2.8 years $(13.9 \%$ vs $15.5 \%$; $P=.47)$ with experienced harvesters, although SVG patency specifically was not evaluated on imaging. ${ }^{36}$ More recent intermediate findings of the REGROUP trial at a median follow-up of 4.7 years suggest a sustained comparable rate of MACE between endoscopic and open approaches. ${ }^{37}$ Follow-up is planned for 10 years to assess long-term outcomes.

Although increasing evidence supports NT-SVG over skeletonized SVG with open techniques, endoscopic techniques have predominantly used skeletonized SVGs, and concerns remain regarding the quality of the SVGs and their longer-term patency. A recent, albeit small, case series highlighted the opportunity to have the best of both worlds by performing minimally invasive NT-SVG harvesting. ${ }^{38}$ Given the predominance and wound advantages of endoscopic SVG harvesting, endoscopic rather than open NTSVG harvesting seems more advantageous, but data related to this technique remain limited to date. ${ }^{39}$

\section{SVG STORAGE SOLUTION}

Grafts are traditionally stored in normal saline with added heparin or in autologous heparinized blood. However, normal saline is acidic and thus detrimental to vascular endothelium. Conversely, autologous heparinized blood has shown inconsistent findings across studies, with unclear benefits and harms. ${ }^{40,41}$ Recently, balanced salt solutions with antioxidants and glutathione have been proposed as a better alternative to achieve a more physiologic $\mathrm{pH}$, although the level of evidence remains minimal in the absence of larger trials (Table 1). An observational study conducted within the PREVENT IV trial suggested that vein grafts stored in buffered saline are associated with improved patency over time. ${ }^{42}$ In an RCT $(n=125)$ comparing the intraoperative use of buffered solution with additional glutathione, L-ascorbic acid, and L-arginine (DuraGraft; Somahlution, Jupiter, Fla) versus heparinized saline, Perrault and associates ${ }^{26}$ assessed wall thickness, lumen diameter, and maximum graft narrowing at 1,3 , and 12 months and found comparable SVG wall thickness changes and graft occlusion at 3 months (primary outcome), whereas secondary graft outcomes at 12 months favored the test solution. Thus, further study is warranted to elucidate the effects of different storage solutions on intermediate and long-term SVG patency. In Europe, the prospective, multicentric VASC registry is assessing the safety and performance of treatment of vascular grafts with DuraGraft in 2964 CABG patients over 5 years (ClinicalTrials.gov identifier NCT02922088). The primary outcome assesses annual MACE rates up to 5 years; Secondary outcomes include MACCE rates at 1 month and annually up to 5 years, quality of life (via EQ-5D-5L) annually up to 5 years, and healthcare resource utilization costs annually up to 5 years.

\section{PHARMACOTHERAPY}

Secondary preventative therapies are essential to maintain graft patency. The AHA recommends the use of antiplatelet (class I; LoE A) and statin (class I; LoE A) therapy post-CABG for all patients. ${ }^{43}$ Reduction of prothrombotic states post-CABG improves graft patency rates and prevents atherothrombotic complications. The AHA recommends that aspirin be administered preoperatively and within 6 hours post-CABG at doses of 81 to $325 \mathrm{mg}$ daily and then continued indefinitely thereafter (class I; LoE A). The use of dual antiplatelet therapy over monotherapy with aspirin to improve graft patency is supported by the AHA in cases of off-pump CABG (class I; LoE A), but the benefits are not well established for patients with on-pump CABG (class IIb; LoE A). In a recent network meta-analysis $(n=4803),{ }^{44}$ high-certainty evidence that demonstrated the use of aspirin with clopidogrel (OR, $0.60 ; 95 \%$ CI, 0.42-0.86) or ticagrelor (OR, 0.50; 95\% CI, 0.31-0.79) was associated with reduced graft occlusion compared with aspirin alone. However, when only studies with on-pump CABG were analyzed, the use of aspirin with ticagrelor $(\mathrm{OR}, 0.51 ; 95 \% \mathrm{CI}, 0.32-0.80)$, but not with clopidogrel (OR, 0.68 ; 95\% CI, 0.43-1.07) was associated with reduced graft vein occlusion. These results are encouraging, as dual antiplatelet therapy strategies do not appear to increase the risk of major bleeding or myocardial infarction in these patients. Nevertheless, trial evidence regarding single-antiplatelet (ticagrelor) versus dual antiplatelet (ticagrelor plus aspirin) therapy remains inconsistent. The Different Antiplatelet Therapy Strategy after CABG Surgery $(\mathrm{DACAB})$ trial $(\mathrm{n}=500)^{45}$ showed improved 1-year SVG patency rates after elective CABG with ticagrelor plus aspirin versus aspirin alone $(88.7 \%$ vs $76.5 \% ; P<.001)$, whereas ticagrelor alone versus aspirin did not $(82.8 \%$ vs $76.5 \% ; P=.10)$. In DACAB, $75 \%$ of SVGs were performed with off-pump $\mathrm{CABG},{ }^{46}$ which is consistent with meta-analytic findings suggesting a greater benefit from dual antiplatelet therapy in off-pump CABG patients. ${ }^{47}$ The POPular CABG (Effect of Ticagrelor on 
SVG Patency in Patients Undergoing CABG Surgery) trial, published after the network meta-analysis by Solo and associates ${ }^{44}$ randomized 499 patients to ticagrelor plus aspirin versus aspirin alone and found comparable SVG occlusion rates at 1 year $(10.5 \%$ vs $9.1 \% ; P=.38) .{ }^{48}$ The ongoing Ticagrelor Antiplatelet Therapy to Reduce Graft Events and Thrombosis (TARGET) trial (ClinicalTrials.gov identifier NCT02053909) is randomizing 300 patients to $90 \mathrm{mg}$ of ticagrelor twice daily versus $81 \mathrm{mg}$ of aspirin twice daily to assess SVG occlusion and stenosis at 1 and 2 years.

SVG occlusion due to intimal hyperplasia and atheromatous plaques is related to increased levels of low-density lipoprotein (LDL). For this reason, the AHA recommends that all CABG patients receive statin therapy in the preoperative period and restart early after surgery (class I; LoE A). However, the intensity of therapy remains the subject of current debate. The target LDL of $<100 \mathrm{mg} / \mathrm{dL}$ to prevent SVG disease was established in the Post-Coronary Artery Bypass Graft Trial ${ }^{49}$ and supported by post hoc analysis of the Clopidogrel after Surgery for Coronary Artery Disease (CASCADE) trial. ${ }^{50}$ Even though aggressive lowering of LDL to $<70 \mathrm{mg} / \mathrm{dL}$ in patients with atherosclerotic disease improves cardiac outcomes, achieving this target in CABG patients might not be associated with improved graft patency, as a post hoc analysis of the CASCADE trial revealed no further improvement in graft patency for patients at an LDL of $<70 \mathrm{mg} / \mathrm{dL}$ compared with $<100 \mathrm{mg} / \mathrm{dL}$. This is also supported by recent results from the Aggressive Cholesterol Therapy to Inhibit Vein Graft Events trial, ${ }^{51}$ which revealed no difference in SVG occlusion at 1 year for patients who received $80 \mathrm{mg}$ of atorvastatin compared with those who received $10 \mathrm{mg}$ of atorvastatin. Currently, based on evidence from patients with clinical atherosclerotic cardiovascular disease, the AHA recommends highintensity statin therapy for $\mathrm{CABG}$ patients age $<75$ years (class I; LoE A), owing to the potential for drug-drug interactions and lack of inclusion of patients age $>75$ years in the high-intensity statin trials. Finally, the multicentric NEWTON-CABG RCT $(n=766)$ is evaluating the effect of evolocumab on SVG patency, SVG disease rate, and complete SVG occlusion at 24 months after CABG (ClinicalTrials.gov identifier NCT03900026), in light of the higher PCSK9 levels observed in patients with SVG disease versus those with patent SVGs. ${ }^{52}$

In conclusion, conventional SVGs remain a popular choice of conduit but are subject to less favorable outcomes and patency compared with arterial grafts. However, various techniques exist to improve vein graft patency over time. Larger trials are nearing completion and will undoubtedly shed further light on the role of NT-SVG for nonLAD CABG. The 2021 update of the American College of Cardiology Foundation/AHA guidelines has been published recently, and multisociety guidelines for conduit selection are currently in development. Saphenous vein harvest site complications are limited with endoscopic harvesting techniques and are safe in experienced hands. The results of the Food and Drug Administration's pivotal study of external stenting will be reported shortly. The use of balanced salt solutions and complementary pharmacotherapy may further enhance vein graft patency. Although the growing adoption and evidence in favor of multiple arterial grafting are promising, continuing improvements in SVG patency and outcomes for our patients remain essential.

\section{Conflict of Interest Statement}

Dr Fremes is Principal Investigator of Canadian Institute of Health Research-funded ROMA grant, CoA of National Institutes of Health-funded ROMA-QofL, CoA of National Institutes of Health-funded ROMA-Cog. Dr Vervoort and Author Malik reported no conflicts of interest.

The Journal policy requires editors and reviewers to disclose conflicts of interest and to decline handling or reviewing manuscripts for which they may have a conflict of interest. The editors and reviewers of this article have no conflicts of interest.

\section{References}

1. Gaudino M, Lorusso R, Rahouma M, Abouarab A, Tam DY, Spadaccio C, et al. Radial artery versus right internal thoracic artery versus saphenous vein as the second conduit for coronary artery bypass surgery: a network meta-analysis of clinical outcomes. J Am Heart Assoc. 2019;8:e010839.

2. Gaudino M, Benedetto U, Fremes S, Biondi-Zoccai G, Sedrakyan A, Puskas JD, et al. Radial-artery or saphenous-vein grafts in coronary-artery bypass surgery. $N$ Engl J Med. 2018;378:2069-77.

3. Gaudino M, Benedetto U, Fremes S, Ballman K, Biondi-Zoccai G, Sedrakyan A, et al. Association of radial artery graft vs saphenous vein graft with long-term cardiovascular outcomes among patients undergoing coronary artery bypass grafting: a systematic review and meta-analysis. JAMA. 2020;324:179-87.

4. Aldea GS, Bakaeen FG, Pal J, Fremes S, Head SJ, Sabik J, et al. The Society of Thoracic Surgeons clinical practice guidelines on arterial conduits for coronary artery bypass grafting. Ann Thorac Surg. 2016;101:801-9.

5. Sabik JF III. Understanding saphenous vein graft patency. Circulation. 2011;124: 273-5.

6. Alexander JH, Hafley G, Harrington RA, Peterson ED, Ferguson TB Jr, Lorenz TJ, et al. Efficacy and safety of edifoligide, an E2F transcription factor decoy, for prevention of vein graft failure following coronary artery bypass graft surgery: PREVENT IV: a randomized controlled trial. JAMA. 2005;294:2446-54.

7. Antonopoulos AS, Odutayo A, Oikonomou EK, Trivella M, Petrou M, Collins GS, et al. Development of a risk score for early saphenous vein graft failure: an individual patient data meta-analysis. J Thorac Cardiovasc Surg. 2020; 160:116-27.e4.

8. Souza D. A new no-touch preparation technique. Technical notes. Scand J Thorac Cardiovasc Surg. 1996;30:41-4.

9. Samano N, Bodin L, Karlsson J, Geijer H, Arbeus M, Souza D. Graft patency is associated with higher health-related quality of life after coronary artery bypass surgery. Interact Cardiovasc Thorac Surg. 2017;24:388-94.

10. Neumann FJ, Sousa-Uva M, Ahlsson A, Alfonso F, Banning AP, Benedetto U, et al. 2018 ESC/EACTS guidelines on myocardial revascularization. EuroIntervention. 2019;14:1435-534.

11. Samano N, Geijer H, Liden M, Fremes S, Bodin L, Souza D. The no-touch saphenous vein for coronary artery bypass grafting maintains a patency, after 16 years, comparable to the left internal thoracic artery: a randomized trial. J Thorac Cardiovasc Surg. 2015;150:880-8.

12. Dreifaldt M, Mannion JD, Geijer H, Lidén M, Bodin L, Souza D. The no-touch saphenous vein is an excellent alternative conduit to the radial artery 8 years after coronary artery bypass grafting: a randomized trial. J Thorac Cardiovasc Surg. 2021;161:624-30. 
13. Hillis LD, Smith PK, Anderson JL, Bittl JA, Bridges CR, Byrne JG, et al. 2011 ACCF/AHA guideline for coronary artery bypass graft surgery: a report of the American College of Cardiology Foundation/American Heart Association task force on practice guidelines. Circulation. 2011;124:e652-735.

14. Dreifaldt M, Mannion JD, Bodin L, Olsson H, Zagozdzon L, Souza D. The notouch saphenous vein as the preferred second conduit for coronary artery bypass grafting. Ann Thorac Surg. 2013;96:105-11.

15. Souza DSR, Dashwood MR, Tsui JCS, Filbey D, Bodin L, Johansson B, et al. Improved patency in vein grafts harvested with surrounding tissue: results of a randomized study using three harvesting techniques. Ann Thorac Surg. 2002; 73:1189-95.

16. Souza DSR, Johansson B, Bojö L, Karlsson R, Geijer H, Filbey D, et al. Harvesting the saphenous vein with surrounding tissue for $\mathrm{CABG}$ provides long-term graft patency comparable to the left internal thoracic artery: results of a randomized longitudinal trial. J Thorac Cardiovasc Surg. 2006;132:373-8.

17. Verma S, Lovren F, Pan Y, Yanagawa B, Deb S, Karkhanis R, et al. Pedicled notouch saphenous vein graft harvest limits vascular smooth muscle cell activation: the PATENT saphenous vein graft study. Eur J Cardiothorac Surg. 2014;45: 717-25.

18. Deb S, Singh SK, de Souza D, Chu MWA, Whitlock R, Meyer SR, et al. SUPERIOR SVG: no touch saphenous harvesting to improve patency following coronary bypass grafting (a multicentre randomized control trial, NCT01047449). J Cardiothorac Surg. 2019; 14:85.

19. Pettersen Ø, Haram PM, Winnerkvist A, Karevold A, Wahba A, Stenvik M, et al. Pedicled vein grafts in coronary surgery: perioperative data from a randomized trial. Ann Thorac Surg. 2017;104:1313-7.

20. Ragnarsson S, Janiec M, Modrau IS, Dreifaldt M, Ericsson A, Holmgren A, et al. No-touch saphenous vein grafts in coronary artery surgery (SWEDEGRAFT): rationale and design of a multicenter, prospective, registry-based randomized clinical trial. Am Heart J. 2020;224:17-24.

21. Wang X, Tian M, Zheng Z, Gao H, Wang Y, Wang L, et al. Rationale and design of a multicenter randomized trial to compare the graft patency between no-touch vein harvesting technique and conventional approach in coronary artery bypass graft surgery. Am Heart J. 2019;210:75-80.

22. Kim KB, Hwang HY, Hahn S, Kim JS, Oh SJ. A randomized comparison of the Saphenous Vein Versus Right Internal Thoracic Artery as a Y-Composite Graft (SAVE RITA) trial: one-year angiographic results and mid-term clinical outcomes. J Thorac Cardiovasc Surg. 2014;148:901-7; discussion 907-8.

23. Taggart DP, Ben Gal Y, Lees B, Patel N, Webb C, Rehman SM, et al. A randomized trial of external stenting for saphenous vein grafts in coronary artery bypass grafting. Ann Thorac Surg. 2015;99:2039-45.

24. Taggart DP, Gavrilov Y, Krasopoulos G, Rajakaruna C, Zacharias J, De Silva R, et al. External stenting and disease progression in saphenous vein grafts two years after coronary artery bypass grafting: a multicenter randomized trial. J Thorac Cardiovasc Surg. April 21, 2021 [Epub ahead of print].

25. Taggart DP, Webb CM, Desouza A, Yadav R, Channon KM, De Robertis F, et al. Long-term performance of an external stent for saphenous vein grafts: the VEST IV trial. J Cardiothorac Surg. 2018;13:117.

26. Perrault LP, Carrier M, Voisine P, Olsen PS, Noiseux N, Jeanmart H, et al Sequential multidetector computed tomography assessments after venous graft treatment solution in coronary artery bypass grafting. J Thorac Cardiovasc Surg. 2021;161:96-106.e2.

27. Gaudino M, Hameed I, Robinson NB, Ruan Y, Rahouma M, Naik A, et al. Angiographic patency of coronary artery bypass conduits: a network meta-analysis of randomized trials. J Am Heart Assoc. 2021;10:e019206.

28. Kim YH, Oh HC, Choi JW, Hwang HY, Kim KB. No-touch saphenous vein harvesting may improve further the patency of saphenous vein composite grafts: early outcomes and 1-year angiographic results. Ann Thorac Surg. 2017;103: 1489-97.

29. Taggart DP, Amin S, Djordjevic J, Oikonomou EK, Thomas S, Kampoli AM, et al. A prospective study of external stenting of saphenous vein grafts to the right coronary artery: the VEST II study. Eur J Cardiothorac Surg. 2017;51:952-8.

30. Dangel M, Löwe B, Pfeiffer S, Gulielmos V, Schüler S. [A comparative study of minimal invasive harvesting of vena saphena magna segments]. Langenbecks Arch Chir Suppl Kongressbd. 1998;115:1305-7 [in German].

31. Sastry P, Rivinius R, Harvey R, Parker RA, Rahm AK, Thomas D, et al. The influence of endoscopic vein harvesting on outcomes after coronary bypass grafting: a meta-analysis of 267,525 patients. Eur J Cardiothorac Surg. 2013;44:980-9.

32. Lin TY, Chiu KM, Wang MJ, Chu SH. Carbon dioxide embolism during endoscopic saphenous vein harvesting in coronary artery bypass surgery. J Thorac Cardiovasc Surg. 2003;126:2011-5.
33. Chiu KM, Lin TY, Wang MJ, Chu SH. Reduction of carbon dioxide embolism for endoscopic saphenous vein harvesting. Ann Thorac Surg. 2006;81:1697-9.

34. Lopes RD, Hafley GE, Allen KB, Ferguson TB, Peterson ED, Harrington RA, et al. Endoscopic versus open vein-graft harvesting in coronary-artery bypass surgery. N Engl J Med. 2009;361:235-44.

35. Puskas JD, Halkos ME, Balkhy H, Caskey M, Connolly M, Crouch J, et al. Evaluation of the PAS-Port proximal anastomosis system in coronary artery bypass surgery (the EPIC trial). J Thorac Cardiovasc Surg. 2009;138:125-32.

36. Zenati MA, Bhatt DL, Bakaeen FG, Stock EM, Biswas K, Gaziano JM, et al Randomized trial of endoscopic or open vein-graft harvesting for coronaryartery bypass. N Engl J Med. 2019;380:132-41.

37. Zenati MA, Bhatt DL, Stock EM, Hattler B, Wagner TH, Bakaeen FG, et al. Intermediate-term outcomes of endoscopic or open vein harvesting for coronary artery bypass grafting: the REGROUP randomized clinical trial. JAMA Netw Open 2021;4:e211439.

38. Hayashi I, Kashima I, Yoshikawa E. Use of the no-touch saphenous vein harvesting technique via small incisions. Innovations (Phila). 2020;15:81-4.

39. Hayashi I, Kashima I, Yoshikawa E. The endoscopic no-touch saphenous vein harvesting technique. Multimed Man Cardiothorac Surg. 2020;2020.

40. Tsakok M, Montgomery-Taylor S, Tsakok T. Storage of saphenous vein grafts prior to coronary artery bypass grafting: is autologous whole blood more effective than saline in preserving graft function? Interact Cardiovasc Thorac Surg 2012:15:720-5.

41. Eqbal A, Gupta S, Bisleri G. Storage solutions to improve grafts preservation and longevity in coronary artery bypass grafting surgery: hype or hope? Curr Opin Cardiol. 2021;36:616-22.

42. Harskamp RE, Alexander JH, Schulte PJ, Brophy CM, Mack MJ, Peterson ED et al. Vein graft preservation solutions, patency, and outcomes after coronary artery bypass graft surgery: follow-up from the PREVENT IV randomized clinical trial. JAMA Surg. 2014;149:798-805.

43. Kulik A, Ruel M, Jneid H, Ferguson TB, Hiratzka LF, Ikonomidis JS, et al. Secondary prevention after coronary artery bypass graft surgery: a scientific statement from the American Heart Association. Circulation. 2015;131:927-64.

44. Solo K, Lavi S, Kabali C, Levine GN, Kulik A, John-Baptiste AA, et al. Antithrombotic treatment after coronary artery bypass graft surgery: systematic review and network meta-analysis. BMJ. 2019;367:15476.

45. Zhao Q, Zhu Y, Xu Z, Cheng Z, Mei J, Che X, et al. Effect of ticagrelor plus aspirin, ticagrelor alone, or aspirin alone on saphenous vein graft patency 1 year after coronary artery bypass grafting: a randomized clinical trial. JAMA. 2018;319:1677-86.

46. Xenogiannis I, Zenati M, Bhatt DL, Rao SV, Rodés-Cabau J, Goldman S, et al Saphenous vein graft failure: from pathophysiology to prevention and treatmen strategies. Circulation. 2021;144:728-45.

47. Deo SV, Dunlay SM, Shah IK, Altarabsheh SE, Erwin PJ, Boilson BA, et al. Dual anti-platelet therapy after coronary artery bypass grafting: is there any benefit? A systematic review and meta-analysis. J Card Surg. 2013;28:109-16.

48. Willemsen LM, Janssen PWA, Peper J, Soliman-Hamad MA, van Straten AHM, Klein $\mathrm{P}$, et al. Effect of adding ticagrelor to standard aspirin on saphenous vein graft patency in patients undergoing coronary artery bypass grafting (POPular CABG): a randomized, double-blind, placebo-controlled trial. Circulation. 2020;142:1799-807.

49. Post Coronary Artery Bypass Graft Trial Investigators. The effect of aggressive lowering of low-density lipoprotein cholesterol levels and low-dose anticoagulation on obstructive changes in saphenous-vein coronary-artery bypass grafts. $N$ Engl J Med. 1997;336:153-62.

50. Kulik A, Voisine P, Mathieu P, Masters RG, Mesana TG, Le May MR, et al. Statin therapy and saphenous vein graft disease after coronary bypass surgery: analysis from the CASCADE randomized trial. Ann Thorac Surg. 2011;92:1284-90; discussion 1290-1.

51. Kulik A, Abreu AM, Boronat V, Ruel M. Intensive versus moderate statin therapy and early graft occlusion after coronary bypass surgery: the Aggressive Cholesterol Therapy to Inhibit Vein Graft Events randomized clinical trial. J Thorac Cardiovasc Surg. 2019;157:151-61.e1.

52. Gao J, Wang HB, Xiao JY, Ren M, Reilly KH, Li YM, et al. Association between proprotein convertase subtilisin/kexin type 9 and late saphenous vein graft disease after coronary artery bypass grafting: a cross-sectional study. BMJ Open. 2018;8:e021951.

Key Words: coronary artery bypass grafting, arterial grafting, vein graft, patency, saphenous vein graft 